\section{A Rapid Enzyme Immunoassay for Cocaine and Benzoylecgonine Using Glucose Oxidase}

\author{
Mitsune Yamaguchi, ${ }^{a}$ Hiromi Inoue, ${ }^{a}$ \\ Toshiyuki Chikuma, ${ }^{a}$ Junko Itoh, ${ }^{a}$ \\ Yukiko Makino, ${ }^{b}$ and Hiroshi Hojo ${ }^{*, a}$ \\ ${ }^{a}$ Department of Hygienic Chemistry, Showa Pharmaceutical \\ University, 3-3165 Higashitamagawagakuen, Machida, Tokyo \\ 194-8543, Japan and 'Kanto-Shin' etsu Regional Narcotic \\ Control Office, Ministry of Health, Labor and Welfare, 2-4-14 \\ Nakameguro, Meguro-ku, Tokyo 153-0061, Japan \\ (Received April 9, 2001; Accepted April 24, 2001)
}

A rapid enzyme immunoassay (EIA) for cocaine and its main metabolite, benzoylecgonine (BZE), using glucose oxidase (GOD) was established. Drug concentrations in samples were determined by the inhibition test. BZE-conjugated GOD and samples were added into the wells of a 96-well microtest plate coated with anti-BZE monoclonal antibody. After washings, color development was performed by additions of glucose, horse radish peroxidase (HRP) and $3,3^{\prime}, 5,5^{\prime}$ tetramethylbenzidine (TMB), which was a non-mutagenic and non-carcinogenic chromogen. The time required for the immune reaction and the subsequent color development was only $12 \mathrm{~min}$ in this EIA. The EIA specifically detected cocaine and BZE at the low detection limit, that is, about $45.4 \mathrm{pg} /$ well for cocaine, and $433 \mathrm{pg} /$ well for BZE, respectively. The values were hardly interfered by urine diluted to $10 \%$. The present assay method was rapid, sensitive, simple, and safe, and was easily carried out anyplace a micro-plate reader was available. Therefore, it might be suitable to screen cocaine and BZE in urine at the scene of abuse.

Key words — enzyme immunoassay, glucose oxidase, cocaine, benzoylecgonine

\section{INTRODUCTION}

The illegal use of narcotics and stimulants has been increasing around the world. To deal with such

*To whom correspondence should be addressed: Department of Hygienic Chemistry, Showa Pharmaceutical University, 3-3165 Higashitamagawagakuen, Machida, Tokyo 194-8543, Japan. Tel.: +81-42-721-1564; Fax: +81-42-721-1563; E-mail: hojo@ ac.shoyaku.ac.jp drug abuse, rapid and precise analyses are required. Enzyme immunoassays (EIA) are suitable for providing such screens, since biological samples are directly measured without extraction and concentration. Use of EIA for screening drugs requires labeling enzymes and color development systems. In recent years, various EIAs for various drugs have been developed. A variety of enzymes such as alkaline phosphatase, horseradish peroxidase (HRP) and $\beta$-galactosidase, glucose oxidase (GOD), have been used as labels in EIA. ${ }^{1)}$

In the present study, we intended to establish a rapid and easily manipulated EIA for screening cocaine and its main metabolite, benzoylecgonine (BZE), in urine. We chose GOD as a label enzyme because it gives excellent results in combination with free HRP, ${ }^{2)}$ and there is little work with GOD in the field of drug abuse testing. GOD produces hydrogen peroxide by catalyzing the oxidation of $\beta$-D-glucose to D-glucono- $\delta$-lactone in the presence of molecular oxygen. The amount of hydrogen peroxide produced can be detected by a colorimetric method in combination with peroxidase and its substrates (chromogens) such as $o$-phenylenediamine (OPD), 2,2'-azino-bis(3-ethybenz-thiazoline-6-sulfonic acid (ABTS) and 3,3',5,5'-tetramethylbenzidine (TMB). It has been reported that ABTS and OPD are mutagenic and carcinogenic, ${ }^{3)}$ but TMB is neither mutagenic $^{4)}$ nor carcinogenic, ${ }^{5)}$ and TMB is more sensitive than OPD and ABTS in combination with HRP and hydrogen peroxide. ${ }^{6}$ However, TMB has the weak point of being labile in aqueous buffers. Very recently, a stabilization method of TMB solution using tetrabutyl ammoniumborohydride has been established. ${ }^{7)}$

The principle of the present EIA is that the amount of BZE or cocaine in samples is determined by competitive inhibition with BZE-conjugated GOD to anti-BZE-monoclonal antibody coated on a plate. TMB was then used as a chromogen for color development.

\section{MATERIALS AND METHODS}

Regents — GOD derived from Asp. niger (Lot No. SEL7705) ${ }^{8)}$ and TMB were purchased from Wako Pure Chemical Industries (Osaka, Japan). Cocaine hydrochloride and codeine phosphate were purchased from Takeda Chemical Industries, Ltd. (Osaka, Japan). Anti-BZE monoclonal antibody was from Biogenesis Co. (England, U.K.). Ecgonine, 

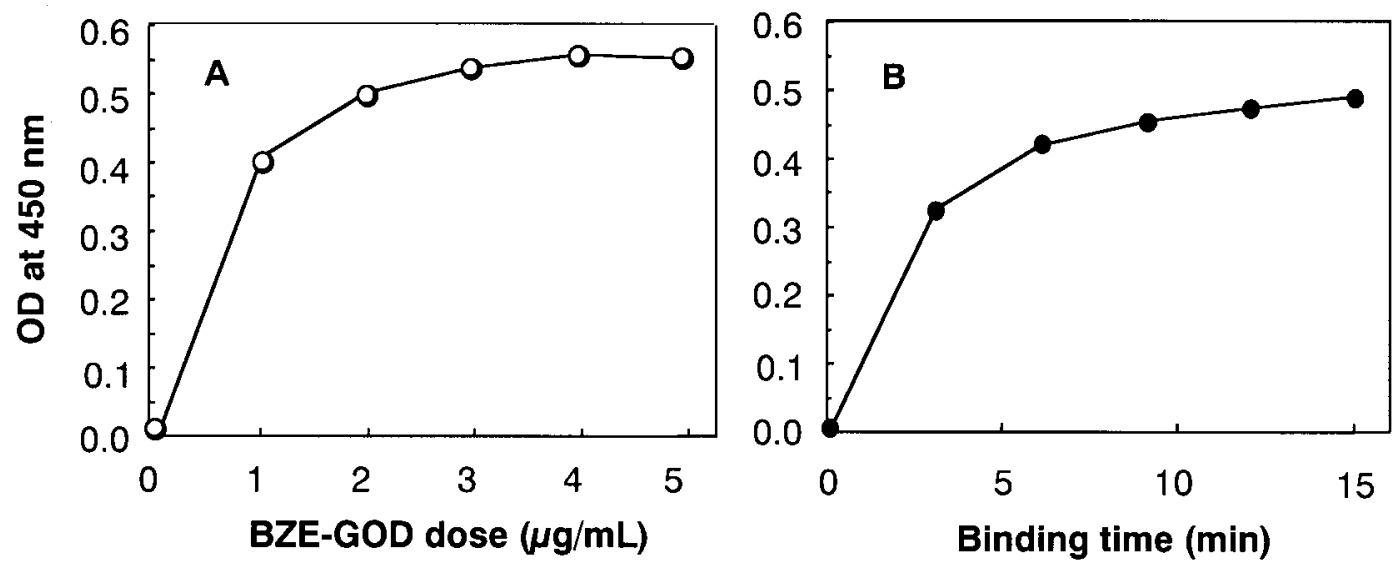

Fig. 1. Amount of BZE-GOD Binding with Anti-BZE Antibody Coated Plates Is Dependent on BZE-GOD Dose (A) and on Time (B)

ecgonine methylester, ethylmorphine, dihydrocodeine, oxymethebanol, pethidine, fentanyl, methamphetamine, and amphetamine were supplied from the custody of the Kanto-Shin'etsu Regional Narcotic Control Office, Ministry of Health and Welfare. BZE was synthesized from cocaine in our laboratory. ${ }^{9)}$ A micro-test plate with 96 wells (F96 Maxsorp Nunc-Immunoplate) was purchased from Nunc (Denmark).

Preparation of BZE-Conjugated GOD (BZEGOD) — BZE was coupled to GOD according to the modified Wainer's method. ${ }^{10,11)}$ Briefly, a mixture of $100 \mathrm{mg}$ of BZE, $45 \mu \mathrm{l}$ of isobutylchloroformate and $8.2 \mu \mathrm{l}$ of tributylamine was dissolved in $1 \mathrm{ml}$ of dimethylformamide and stirred at $4{ }^{\circ} \mathrm{C}$ for $30 \mathrm{~min}$, and then supplied with $1 \mathrm{ml}$ of water (solution A). GOD solution $(128 \mathrm{mg} / \mathrm{ml}$ water) was mixed with $1 \mathrm{ml}$ of dimethylformamide and incubated at $4^{\circ} \mathrm{C}$ for 30 min at $\mathrm{pH} 8.5$ (solution B). Then, both solution $\mathrm{A}$ and $\mathrm{B}$ were reacted at $\mathrm{pH} 8.5$ at $4^{\circ} \mathrm{C}$ for $4 \mathrm{hr}$, and dialyzed against water for 3 days and lyophilized.

EIA — Wells of the micro-test plate were coated with $100 \mu \mathrm{l}$ of anti-BZE antibody $(1 \mu \mathrm{g} / \mathrm{ml}$ of $0.05 \mathrm{M}$ carbonate-bicarbonate buffer, $\mathrm{pH} 9.6)$ at $4{ }^{\circ} \mathrm{C}$ overnight, blocked with $0.5 \%$ skimmed milk in $0.05 \%$ Tween 20-PBS (T-PBS) and washed twice with TPBS. For drawing a standard inhibition curve, $50 \mu \mathrm{l}$ of BZE-GOD $(5 \mu \mathrm{g} / \mathrm{ml})$ and $50 \mu$ l of several concentrations of cocaine or BZE were added into the antibody-coated plate and reacted for $15 \mathrm{~min}$ at room temperature. After triple washings, a mixture $(100 \mu \mathrm{l})$ of glucose $(1 \mathrm{mg})$, HRP $(5 \mathrm{ng})$ and TMB $(20 \mathrm{nmol})$ was added into the wells and incubated at room temperature for several minutes. The reaction was stopped by the addition of $50 \mu$ of $1 \mathrm{M}$ sulfuric acid, and the absorbance at $450 \mathrm{~nm}$ was measured by a micro-plate reader (Model 3550, Biorad, CA, U.S.A.).

\section{RESULTS AND DISCUSSION}

The purpose of this work was to construct a rapid, sensitive and handy EIA for screening cocaine and BZE. The optimal assay conditions for this EIA were first examined. Then, competitive inhibitions by various drugs were evaluated.

\section{Optimal Assay Conditions for EIA}

We selected GOD as an enzyme label. First, the amount of BZE-GOD binding to anti-BZE monoclonal antibody coated on a 96 -well microtest plate was examined. The binding of BZE-GOD with the antibody was dose-dependently increased and almost maximal at $3 \mu \mathrm{g} / \mathrm{ml}$ when incubated for $15 \mathrm{~min}$ (Fig. 1A), and approximate equilibrium was achieved in $6 \mathrm{~min}$ when $2.5 \mu \mathrm{g} / \mathrm{ml}$ of BZE-GOD was used (Fig. 1B).

Second, the conditions for color development were examined. In order to measure hydrogen peroxide produced by GOD from glucose, the combination of HRP and TMB, which was one of the most sensitive enzymatic detection systems, ${ }^{6)}$ was applied in this EIA. In the case of the EIA in which HRP was used as a label, a substrate solution of diluted hydrogen peroxide had to be prepared from a bit of toxic and dangerous hydrogen peroxide stock solution $(e . g .30 \% \mathrm{v} / \mathrm{v})$ immediately prior to use. Therefore, the use of HRP as a label is not reasonable. When $2.5 \mu \mathrm{g} / \mathrm{ml}$ of BZE-GOD was incubated with anti-BZE antibody for $15 \mathrm{~min}$, color was maximally 

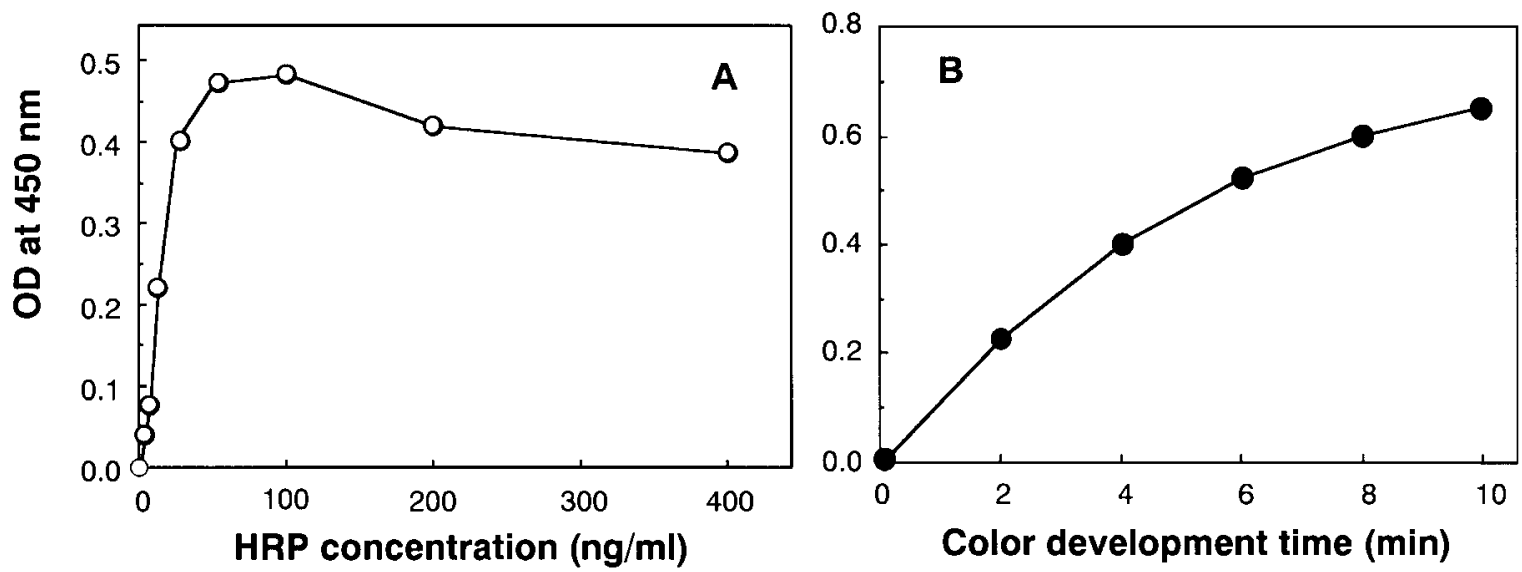

Fig. 2. Relations between HRP Concentration and Color Development (A), and between Incubation Time and Color Development (B)

developed in the range of $50-100 \mathrm{ng} / \mathrm{ml}$ of HRP (Fig. 2A) and increased in a time-dependent manner in the first 6 min (Fig. 2B). It took $12 \mathrm{~min}$ at a minimum for both the binding between BZE-GOD and anti-BZE antibody and the color development in the EIA. TMB is a non-mutagenic and non-carcinogenic chromogen. ${ }^{4,5,12)}$ The safety of reagents is the most important prerequisite for assays used anyplace other than the laboratory.

\section{Competitive Inhibition by Various Drugs of the Binding between BZE-GOD and Anti-BZE Anti- body}

The competitive inhibition by cocaine or BZE of the binding between BZE-GOD and anti-BZE antibody is shown in Fig. 3. The measurable doses were in the range of 3-400 $\mathrm{nM}(45.5-6060 \mathrm{pg} / \mathrm{well})$ for cocaine and 30-1000 $\mathrm{nM}(433-14450 \mathrm{pg} / \mathrm{well})$ for BZE, respectively.

Table 1 shows the competitive inhibition by cocaine metabolites and some other drugs. The value of $\mathrm{IC}_{50}$ was $15 \mathrm{nM}$ for cocaine and that for BZE was $180 \mathrm{nM}$. The antibody used was raised against BZE as hapten, but it showed higher reactivity with co-

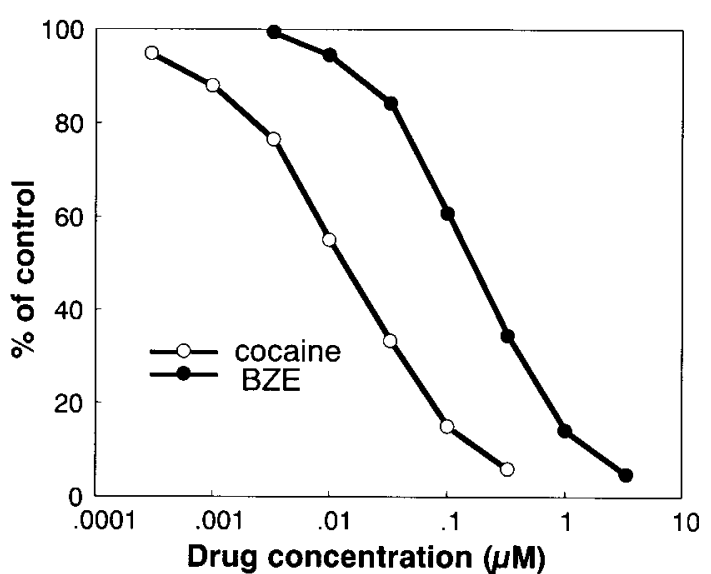

Fig. 3. Calibration Curves of Cocaine (A) and BZE (B) in the EIA

caine than with BZE. Ecgonine methylester inhibited the binding at extremely higher concentrations $\left(\mathrm{IC}_{50}: 3.1 \mathrm{mM}\right)$ than cocaine or BZE did, but the other drugs did not show any inhibition at $1 \mathrm{mM}$. It was important that this EIA system specifically detected cocaine and BZE.

Assay methods based on immune reactions have

Table 1. Inhibition by Various Drugs of BZE-GOD Binding to Anti-BZE Antibody Coated on Plates

\begin{tabular}{lclc}
\hline \hline Drug & $\mathrm{IC}_{50}(\mu \mathrm{M})$ & Drug & $\mathrm{IC}_{50}(\mu \mathrm{M})$ \\
\hline Cocaine & 0.015 & Codeine & $\mathrm{ND}$ \\
Benzoylecgonine & 0.180 & Dehydrocodeine & $\mathrm{ND}$ \\
Ecgonine methylester & 3100.000 & Oxymethebanol & $\mathrm{ND}$ \\
Ecgonine & $\mathrm{ND}$ & Pethidine & $\mathrm{ND}$ \\
Benzoic acid & $\mathrm{ND}$ & Fentanyl & $\mathrm{ND}$ \\
Morphine & $\mathrm{ND}$ & $d$-Methamphetamine & $\mathrm{ND}$ \\
Ethylmorphine & $\mathrm{ND}$ & $l$-Amphetamine & $\mathrm{ND}$ \\
\hline
\end{tabular}

ND: no detectable inhibition over $1000 \mu \mathrm{M}$ 

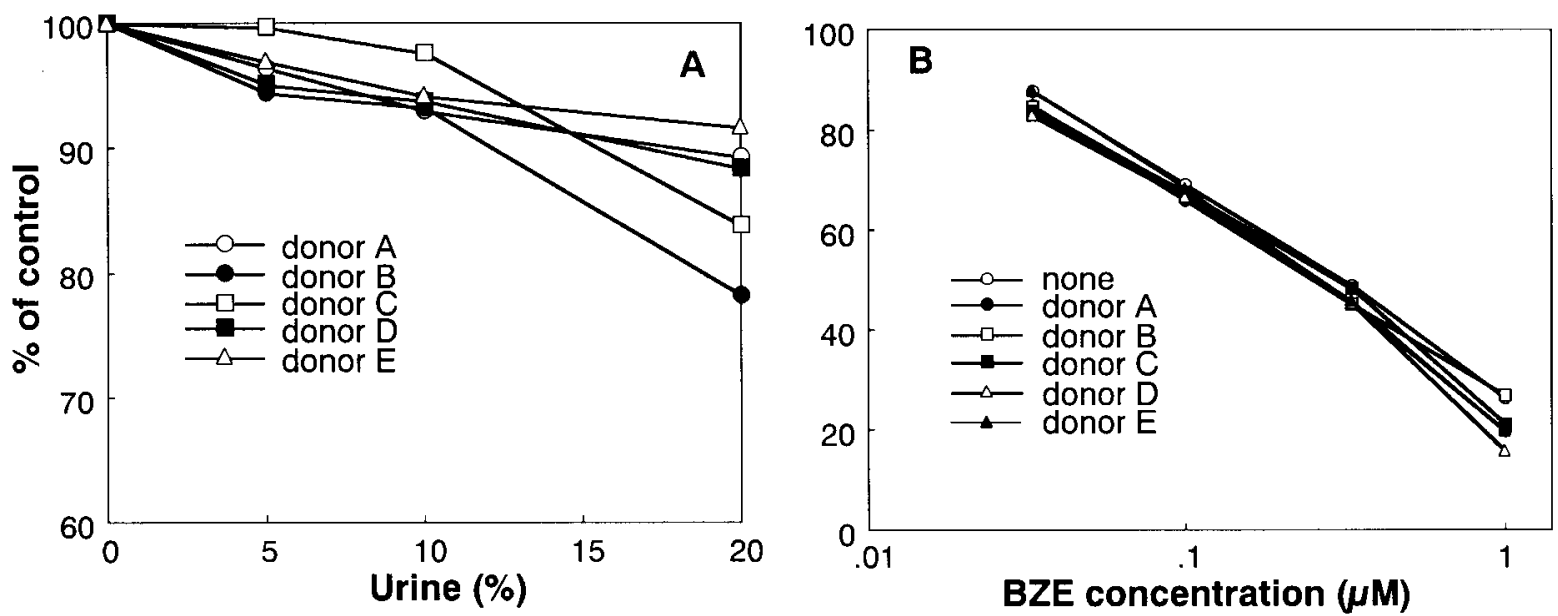

Fig. 4. Effect of Urine Addition on the Binding of BZE-GOD to an Anti-BZE Antibody Coated Plate (A) and on the Calibration Curve of BZE (B)

advantages of being directly applicable to biological samples. However, they are often interfered with specifically or nonspecifically by biological components. We tested whether the present EIA was affected by normal urine. Binding of BZE-GOD with anti-BZE antibody coated on the plate was reduced less than $10 \%$ by the addition of $10 \%$ urine from five donors (Fig. 4A).

However, the calibration curve for BZE was hardly affected by the addition of the same concentration of urine (Fig. 4B), even if glucose $(10 \mathrm{mg} /$ $\mathrm{ml}$ ) was added (data not shown). Therefore, the lowest detectable limit of BZE in urine is calculated as $4.33 \mathrm{ng} /$ well $(86.6 \mathrm{ng} / \mathrm{ml}$ of urine), if urine samples diluted to $10 \%$ are measured.

Cocaine or BZE might be quickly measured by the present method, if an antibody-coated plate has been prepared. This method is specific and sensitive for cocaine and BZE, and is easily and safely manipulated. Therefore, the present EIA might be useful for screening cocaine and BZE in specimens of cocaine abuse.

Acknowledgements This work was supported by a Grant-in Aid for Iyakuhin Anzen Sogo Jigyo from the Ministry of Health, Labor and Welfare of Japan.

\section{REFERENCES}

1) Porstmann, T. and Kiessig, S. T. (1992) Enzyme immunoassay techniques. Overview. J. Immunol. Methods, 150, 5-21.

2) Hosoda, H., Tsukamoto, R., Shoriken, K., Takasaki,
W. and Nambara, T. (1988) Sensivity of steroid enzyme immunoassays. Use of 3,3',5,5'-teramethylbenzidine as a chromogen in the assay system with glucose oxidase label. Chem. Pharm. Bull., 36, 1808-1813.

3) Voogd, C. E., van der Stel, J. J. and Jacobs, J. J. J. A. A. (1980) On the mutagenic action of some enzyme immunoassay substrates. J. Immunol. Methods, 36, 55-61.

4) Garner, R. C., Walpole, A. L. and Rose, F. L. (1975) Testing of some benzidine analogues for microsomal activation to bacterial mutagens. Cancer Lett., 1, 3942.

5) Holland, V. R., Saunders, B. C., Rose, F. L. and Walpole, A. L. (1974) A safer substitute for benzidine in the detection of blood. Tetrahedron, 30, 32993302.

6) Hosoda, H., Takasaki, W., Oe, T., Tsukamoto, R. and Nambara, T. (1986) A comparison of chromogenic substrates for horseradish peroxidase as a label in steroid enzyme immunoassay. Chem. Pharm. Bull., 34, 4177-4182.

7) Frey, A., Meckelein, B., Externest, D. and Schmidt, M. A. (2000) A stable and highly sensitive 3,3',5,5'tetramethylbenzidine-based substrate reagent for enzyme-linked immunosorbent assays. J. Immunol. Methods, 233, 47-56.

8) Swoboda, B. E. P. and Massey, V. (1965) Purification and properties of glucose oxidase from Aspergillus niger. J. Biol. Chem., 240, 2209-2215.

9) Robinson, K. and Smith, R. N. (1984) Radioimmunoassay of benzoylecgonine in samples of forensic interest. J. Pharm. Pharmacol., 36, 157162.

10) Wainer, B. H., Fitch, F. W., Rothberg, F. W. and Fried, J. (1971) Morphine-3-succinyl-bovine serum 
albumin: An immunogenic hapten-protein conjugate. Science, 176, 1143-1145.

11) Aoki, K., Itoh, Y. and Yoshida, T. (1997) Simultaneous determination of urinary metamphetamine, cocaine, and morphine using a latex agglutination inhibition reaction test with colored latex particles. Jpn. J. Toxicol. Environ.
Health, 43, 285-292.

12) Bos, E. S., van der Doelen, A. A, van Rooy, N. and Schuurs, A. H. W. M. (1981) 3,3',5,5'-Tetramethylbenzidine as an Ames test negative chromogen for horseradish peroxidase in enzyme-immunoassay. $J$. Immunoassay, 2, 187-204. 